\title{
sciendo
}

\section{EFFECTS OF PEPPER EXTRACT IN SUCKLING LAMB FEED: GROWTH PERFORMANCE, METABOLISM, AND OXIDATIVE RESPONSES}

\author{
Bruno Giorgio de Oliveia Cécere', Vitor Luiz Molosse', Guilherme Luiz Deolindo', Vanessa Dazuk², Anielen Dutra Silva ${ }^{3}$, \\ Maria Rosa C. Schetinger ${ }^{3}$, Marcelo Vedovatto ${ }^{4}$, Claiton A. Zotti ${ }^{5}$, Aleksandro Schafer da Silva ${ }^{1,2 \bullet}$ \\ ${ }^{1}$ Department of Animal Science, State University of Santa Catarina (UDESC), Chapecó, Brazil \\ ${ }^{2}$ Graduate Program in Animal Science, UDESC, Chapecó, Brazil \\ ${ }^{3}$ Graduate Program in Toxicological Biochemistry, Universidade Federal de Santa Maria, Santa Maria, Brazil \\ ${ }^{4}$ Universidade Estadual de Mato Grosso do Sul, Brazil \\ ${ }^{5}$ Universidade do Oeste de Santa Catarina, Xanxerê, Brazil \\ •Corresponding author: aleksandro.silva@udesc.br
}

\begin{abstract}
Our objective was to determine whether the inclusion of pepper extract would improve health in suckling lambs, stimulating antioxidant activity, and improving performance. We used Lacaune lambs distributed in four treatments, with four repetitions per treatment and three lambs per repetition: control group (T0) and treatments T1, T2, and T3 that received 200, 400, and $800 \mathrm{mg} / \mathrm{kg}$ of pepper extract, respectively. Groups T1 and T2 consumed more significant amounts of silage than group T0, and animals from group T1 consumed more concentrate and, consequently, consumed more solids. The addition of pepper extract enhanced growth performance, with the lowest dose (T1) giving rise to the most significant weight gain, average daily gain, and body weight, compared to T0. Regression analysis showed that the optimum point for pepper extract supplementation was $301.5 \mathrm{mg} / \mathrm{kg}$. The levels of total protein and globulins were significantly higher for animals supplemented with pepper extract (day 28) than the control; the concentrations of albumin and urea increased over time but did not differ significantly among treatments. Serum glucose levels decreased significantly over time; however, the groups supplemented with pepper extract showed higher concentrations than group T0. The hematocrit was significantly higher in groups fed pepper extract; hemoglobin concentrations were also more significant, increasing over time in both groups. The groups that consumed the pepper extract had higher leukocyte counts due to greater lymphocytes and neutrophils. Levels of non-protein thiols increased significantly over time, while lipid peroxidation levels decreased significantly in all groups. The concentrations of reactive oxygen species significantly decreased in the serum of group $\mathrm{T} 3$ animals, those fed with pepper extract (day 28), compared to the control. In general, the addition of pepper extract in lamb feed can enhance weight gain, increase antioxidant levels, and stimulate the production of leukocytes and globulins in lambs.
\end{abstract}

Key words: supplementation, weight gain, antioxidants

Sheep farming requires substantial research owing to its continuous growth worldwide. The final products from sheep, including milk and meat, are high-quality and well-differentiated, both of which are characteristics that add economic value (Magalhães and Lucena, 2019). Nevertheless, sheep farming is challenging because these animals have high capacity and performance; however, their metabolism is accelerated (mainly in the early stages), and inadequate management can lead to major production problems (Cazarotto et al., 2018; Molosse et al., 2019; Cécere et al., 2019). When raising dairy sheep, lambs are taken from their mothers to optimize milk production; the most significant challenge is to develop heavier animals at weaning. Sheep farmers engage in a great deal of milk replacer (Hernandez-Castellano et al., 2015). Lambs in the early stages can be affected by endoparasites and ectoparasites and present severe cases of diarrhea, which may be due to unhealthy or poorly supplied diets, the inadequate temperature of the milk pro- vided, contaminated feed substitutes, or even problems that the facilities may affect the animals (De Oliveira et al., 2013). The growth in demand for sheep meat, associated with the product's sale price, is of particular interest to sheep producers concerned with producing high-quality sheep (Marcon et al., 2021). This means avoiding the production of heavier animals and requires slaughter at early ages while maintaining quantity and quality (Paim et al., 2011; Marcon et al., 2020).

Concerns regarding using antibiotics as performance enhancers in animal feed are well known; indeed, the consumer market has come under substantial pressure to ban these compounds. In Europe, growth promoters have already banned them for several years (Rizzo et al., 2010; Santos et al., 2009). Herbal extracts, essential oils, phytobiotics, and phytogenics are natural additives that partially or even equivalently potentiate growth (Stevanovic et al., 2018). Pepper belongs to the genus Capsicum. Its extract contains oleoresins, characterized by a complex 
source of bioactive properties, in which the most comprehensive active component is capsaicin (8-methyl-Nvanillyl-trans-6-nonenamide) (Wesolowska et al., 2011). These phenolic compounds in pepper give rise to capsaicinoids (Jarupan et al., 2018).

In animals, the active components of pepper exert antioxidant (Pinto et al., 2013; Ochi et al., 2003), antibacterial ( $\mathrm{Gu}$ et al., 2019), and anti-inflammatory effects, as well as stimulating consumption (Santos et al., 2009), increasing amino acids (Rizzo et al., 2010), and protecting the liver from damage (Hassan et al., 2012). Pepper extract demonstrates beneficial and positive results for ruminants (Cunha et al., 2020) and non-ruminants (Jarupan et al., 2018), both related to the health of the animals and the level of their performance. Several studies use capsaicin in blends, mixtures with other vegetable compounds to exploit the synergism that these compounds present, enhancing their biological functions (Jamroz et al., 2003; Frankic et al., 2010; Castillo et al., 2012). Based on the functional properties of pepper extract, the objective of the present study was to determine whether pepper extract would improve performance in infant lambs and improve biochemical characteristics, antioxidant, and immune responses. We hypothesized that the powdered pepper extract in the diet in suckling lambs would improve during weaning, favoring even earlier weaning and a consequent decrease in production costs without harming lamb health.

\section{Material and methods}

\section{Pepper extract}

The feed additive used in this study is a commercial product based on pepper extract (Capsin ${ }^{\circledR}$; Nutriquest). The chemical composition of the pepper extract was analyzed according to AOAC (2000) as follows: dry matter $(920 \mathrm{~g} / \mathrm{kg})$, ether extract $(444 \mathrm{~g} / \mathrm{kg})$, crude protein $(64.4 \mathrm{~g} / \mathrm{kg})$, neutral detergent fiber $(293 \mathrm{~g} / \mathrm{kg})$, and acid detergent fiber $(229 \mathrm{~g} / \mathrm{kg})$. The quantification of capsaicin in the pepper extract was performed using gas chromatography (Peña-Alvarez et al., 2009), giving a concentration of $5.0 \mathrm{~g} / \mathrm{kg}$.

\section{Facilities and animals}

The experiment was carried out on a property in Chapecó-SC (Southern Brazil), where 48 suckling Lacaune lambs were used, 30 days old with an average weight of $9.8 \mathrm{~kg}$, housed in a hut-type shed. The stalls $(1.2 \times 1.5 \mathrm{~m})$ were equipped with water and feed troughs, with three animals per pen. We used lambs at 30 days old because pepper extract was added to the concentrate, a feed that is consumed in substantial quantities during this phase. The newborn lambs spent approximately 8 to 12 hours with their mothers and were then placed in collective pens. Between days 1 to 29 of life, the farmer provided the animals with sheep's milk (1 L/day) and a small amount of concentrate in the feeder to start and encourage the consumption of this feed; we used lambs at 30 days old because the supply of this feed was increased according to consumption; however, there is a significant variation in the amount of concentrate consumed until the 30 days of life of these animals.

\section{Experimental design and food consumption}

The experimental period was 28 days. The lambs were randomly assigned to four groups, four replicates per treatment and three lambs per repetition. The groups were identified as control (T0) for animals that did not receive supplementation with pepper extract; group T1 were lambs that received $200 \mathrm{mg}$ of powdered pepper extract $/ \mathrm{kg}$ of concentrate; group T2 received $400 \mathrm{mg}$ of powdered pepper extract $/ \mathrm{kg}$ of concentrate; and group T3 received $800 \mathrm{mg}$ of powdered pepper extract $/ \mathrm{kg}$ of concentrate.

Table 1. Chemical composition of corn silage and basal concentrate used in the study

\begin{tabular}{lcc}
\hline \multicolumn{1}{c|}{ Items $^{1}$} & Corn silage & Basal concentrate $^{2}$ \\
\hline Dry matter (DM) (\%) & 31.8 & 88.6 \\
Crude protein (CP) (\% DM) & 7 & 22 \\
EE (\% DM) & 4.2 & 3.5 \\
NDF (\% DM) & 38.2 & 12.1 \\
ADF (\% DM) & 21.6 & 6.2 \\
TDN $^{3}$ (\% DM) & 73.7 & 77.6 \\
\hline
\end{tabular}

${ }^{1} \mathrm{DM}$ (dry matter), CP (crude protein), EE (ethereal extract), NDF (neutral detergent fiber), ADF (acid detergent fiber) and NDT (total digestible nutrients).

${ }^{2}$ Ingredients present in $100 \mathrm{~kg}$ of concentrate: ground corn $(650 \mathrm{~g} / \mathrm{kg})$, soybean flour $(300 \mathrm{~g} / \mathrm{kg})$ and pre-mixture $(50 \mathrm{~g} / \mathrm{kg})$. The pre-mixture contained (concentration $/ \mathrm{kg}$ ): calcium min. 180 max. $220 \mathrm{~g}$; phosphorus min. 32 g; sodium min. 40 g; sulfur min. 20 g; magnesium min. 20 g; cobalt min. $16 \mathrm{mg}$; iodine min. $17 \mathrm{mg}$; manganese min. $420 \mathrm{mg}$; selenium min. $730 \mathrm{mg}$; zinc min. $730 \mathrm{mg}$; fluoride max. $600 \mathrm{mg}$; niacin min. $500 \mathrm{mg}$; vitamin A min. $95.000 \mathrm{IU}$; vitamin D min. $20000 \mathrm{IU}$; vitamin E min. $350 \mathrm{IU}$; sodium monensin $1200 \mathrm{mg}$; Saccharomyces cerevisiae $2.1 \times 10^{9} \mathrm{CFU}$.

${ }^{3}$ Calculated as described by Weiss et al. (1992).

The feeding of these animals consisted of a liquid diet of sheep's milk (1 liter per day, divided into two time points: 8:00 am and 5:00 pm), associated with commercial protein concentrate proportional to $2.5 \%$ of live weight (available to animals twice a day, immediately after milk intake) and corn silage ad libitum. The amount of concentrate supplied was based on the average weight of the animals in each stall. The ingredients are displayed in Table 1.

The consumption of concentrate was total. That is, $100 \%$ of the supplied was consumed in all treatments throughout the experiment. The amount of silage consumed was measured at the end of the experiment (days $25,26,27$, and 28) when the volume added to the feeder was weighed several times a day to avoid waste (the feeder was not without silage) and at the end of each day, the remainder was weighed. With this information and the average daily weight gain in this phase, the food efficiency of each treatment was calculated. 


\section{Animal body weight and sample collection}

The lambs were weighed on days 1, 7, 14, 21, and 28 of the experiment using a digital scale. Blood samples were taken on days 1,15 , and 28 of the experiment, a sample taken from the jugular vein. Whole blood was collected in two tubes: a) one without anticoagulant to obtain serum and b) another with EDTA as an anticoagulant for a blood count. The blood collected in tubes without anticoagulant was centrifuged at $3500 \mathrm{rpm}$ for 10 minutes, and the serum was stored frozen $\left(-20^{\circ} \mathrm{C}\right)$ until analysis. The analyses coincided 30 days after the end of the experiment.

Feed samples (corn silage and concentrate) were collected in three experimental periods (day 1, 14, and 28), stored under freezing conditions. At the end of the experiment, a pool was made of the three samples collected, which were used for chemical composition analysis.

\section{Laboratory analyses}

\section{Feed analyses}

In the laboratory, the samples (pool) were pre-dried in a forced-air oven at $55^{\circ} \mathrm{C}$ for 72 hours, then removed from the oven and weighed again to determine the partial dry matter content, followed by grinding in a Wileytype mill (Marconi, model: MA340), using a 1-mm mesh sieve. The pre-dried and ground samples were subjected to heating at $105^{\circ} \mathrm{C}$ to obtain $\mathrm{DM}$, and later to obtain the mineral material in a muffle at $600^{\circ} \mathrm{C}$ (Silva and Queiroz, 2002). CP was determined by the micro-Kjeldahl method (Method 984.13, AOAC, 1997). To determine the levels of neutral detergent fiber (NDF), the samples were packed in polyester bags (Komarek, 1993) and were treated with a neutral detergent solution in an autoclave at $110^{\circ} \mathrm{C}$ for 40 minutes (Senger et al., 2008); for concentrate samples, we included $\alpha$-amylase (Mertens, 2002). The concentrations of acid detergent fiber (ADF) were determined according to AOAC (1997, method 973.18). Tests were performed in triplicate, and results are presented in Table 1.

\section{Serum biochemistries}

The levels of total protein, albumin, urea, glucose, triglycerides, and cholesterol were measured in a semiautomatic analyzer (BioPlus $2000^{\circledR}$ ) using commercial kits (Analisa ${ }^{\circledR}$, Analisa Diagnóstica, Belo Horizonte, Brazil), according to the manufacturer's recommendations. Globulin levels were obtained using the formula: total protein - albumin.

\section{Hemogram}

The number of erythrocytes and total leukocytes and the hemoglobin concentration $(\mathrm{Hb})$ were measured using an automatic $\mathrm{Celm}^{\circledR} 530$ analyzer. The hematocrit was obtained after capillary centrifugation $(1000 \mathrm{rpm}$ in 5 minutes). Blood smears were stained with commercial stain (Romanowsky method) for the leukocyte differential, and a 1000x magnification light microscope was used to process the results (Feldman et al., 2000). The complete blood count analysis was performed within $2 \mathrm{~h}$ after sample collection.

\section{Oxidant and antioxidant status}

Plasma levels of reactive oxygen species (ROS) were analyzed using the method described by Ali et al. (1992). A volume of $10 \mu \mathrm{L}$ of plasma was incubated with $12 \mu \mathrm{L}$ of dichlorofluorescein (DFC) per $\mathrm{ml}$ at $37^{\circ} \mathrm{C}$ for $1 \mathrm{~h}$ in the dark. Fluorescence was determined using $488 \mathrm{~nm}$ for excitation and $520 \mathrm{~nm}$ for emission. The results were expressed as U DCF/mg protein.

Serum lipid peroxidation was measured as the amount of thiobarbituric acid reactive substances (TBARS) according to Jentzsch et al. (1996). The reaction was read in a spectrophotometer at $535 \mathrm{~nm}$. The result was expressed as nmoles malondialdehyde/ $\mathrm{ml}$ of serum.

To measure non-protein thiols (NPSH), the method using 5,5-dithiobis-(2-nitrobenzoic acid) (Sigma) was based on Sedlak and Lindsay (1968). The determination of the NPSH content in the samples was measured after deproteinization with trichloroacetic acid (TCA 50\%). The absorbance readings (405 $\mathrm{nm}$ ) were performed using a spectrofluorometer (Biotek, Synergy HT).

Glutathione S-transferase (GST) activity was measured according to Mannervik and Guthenberg (1981), with modifications. GST activity was measured as the formation rate of dinitrophenyl-S-glutathione at $340 \mathrm{~nm}$ in a medium containing $50 \mathrm{mM}$ potassium phosphate, $\mathrm{pH}$ 6.5, $1 \mathrm{mM}$ GSH, $1 \mathrm{mM}$ 1-chloro-2,4-dinitrobenzene (CDNB) (approximately $0.045 \mathrm{mg}$ protein). The results were calculated and expressed as U GST/mg protein.

\section{Statistical analysis}

All data were analyzed using the MIXED procedure of SAS (SAS Inst. Inc., Cary, NC, USA; version 9.4), with the Satterthwaite approximation to determine the denominator degrees of freedom for the test of fixed effects. The weight gain and average daily gain were tested for fixed effects of treatment and using pen (treatment) and animal (pen) as random variables. All other variables (body weight, serum biochemistries, hemograms, and antioxidant variables) were analyzed as repeated measures and tested for fixed effects of treatment, day, and treatment $\times$ day, and using pen (treatment) and animal (pen) as random variables. All results obtained on $\mathrm{d} 1$ for each variable were also included as covariates; however, the command for covariate was removed from the model when $\mathrm{P}>0.05$. The compound symmetric covariance structure was selected $\mathrm{BW}$; the Toeplitz covariance structure was selected for serum concentration of glucose and hematocrit, neutrophils, and eosinophils; and the first-order autoregressive covariance structure was selected for all other variables. The covariance structures were selected according to the lowest Akaike information criterion. Means were separated using PDIFF, and all results were reported as LSMEANS followed by SEM. Regression analysis using weight gain during the trial period assessed the linear, quadratic, and square root effects. Significance was defined when $\mathrm{P} \leq 0.05$. 


\section{Results}

\section{Growth performance and feed consumption}

The performance results are shown in Table 2. Effects of treatment $(\mathrm{P}=0.01)$, day $(\mathrm{P}=0.01$, ) and the treatment versus day $(\mathrm{P}=0.01)$ interaction were observed for weight gain, and animals supplemented with pepper extract had higher body weight on day 28 of the experiment. Among the dosages of the extract used, lambs from T1 obtained greater live weight on day 28 compared to animals in groups T2 and T3. Over time, we found that lambs in the T1 group showed more significant weight gain (days 1 to $14 ; 1$ to 28$)$ than the other treatments $(\mathrm{P}=$ $0.01)$. The animals supplemented with pepper extract had higher average daily weight gain (DWG) $(\mathrm{P}=0.01)$ (days 1 to $14 ; 1$ to 28 ) when compared to T0 lambs. Among the dosages used, lambs T1 had greater DWG (days 1 to 14; 1 to 28) when compared to groups T2 and T3.

There was no linear $(\mathrm{P}=0.39)$ or quadratic $(\mathrm{P}=$ 0.053 ) effect for weight gain; however, a square root effect was observed $(\mathrm{P}=0.049)$. Therefore, the optimum point for pepper extract supplementation was $301.5 \mathrm{mg} /$ $\mathrm{kg}\left(\mathrm{R}^{2}=0.26\right)$.

Lambs from T1 and T2 consumed a greater amount of silage at the end of the experiment (Table 2), and lambs from $\mathrm{T} 1$ greater amounts of concentrate and consequent- ly greater amounts of solid diet (silage + concentrate) (Table 2).

\section{Metabolism}

The results of the serum biochemistries are presented in Table 3. There was a decrease in albumin levels in the T2 group (day 28) and an increase in the T3 group (day 28). The total protein concentrations in the serum affected the day $(P=0.01)$ and the interaction treatment versus day $(\mathrm{P}=0.01)$. Lambs $\mathrm{T} 1, \mathrm{~T} 2$, and $\mathrm{T} 3$ had higher concentrations on day 28; however, animals in the T2 and T3 groups showed higher concentrations on day 28 than $\mathrm{T} 0$. For serum globulin levels, effects of the day $(P=0.01)$ and in the treatment versus day interaction $(\mathrm{P}=0.03)$ were detected, suggesting that lambs supplemented with pepper extract had higher levels of globulins compared to T0 (day 28). There were effects of the day ( $\mathrm{P}=0.01$ ) for urea levels, where both groups rose over time. There were effects of the day $(\mathrm{P}=0.01)$, and the treatment-day interaction $(\mathrm{P}=0.01)$ for serum glucose concentrations, i.e., lambs $\mathrm{T} 1, \mathrm{~T} 2$, and $\mathrm{T} 3$ showed higher concentrations on day 28 compared to T0; however, over time, glucose levels tended to decrease for groups supplemented with pepper extract; however, compared to T0, the treated groups remained at higher levels. No difference for the variables cholesterol and triglycerides was detected.

Table 2. Growth performance of lambs supplemented with pepper extract mixed in the concentrate

\begin{tabular}{|c|c|c|c|c|c|c|c|c|}
\hline \multirow[b]{2}{*}{ Variables } & \multicolumn{4}{|c|}{ Treatments $^{1}$} & \multirow[b]{2}{*}{ SEM } & \multicolumn{3}{|c|}{ P-value } \\
\hline & $\mathrm{C}$ & $\mathrm{T} 1$ & $\mathrm{~T} 2$ & $\mathrm{~T} 3$ & & treat & day & $\begin{array}{c}\text { treat } \times \\
\text { day }\end{array}$ \\
\hline Body weight (kg) & & & & & & 0.01 & 0.01 & 0.01 \\
\hline d 1 & $9.80 \mathrm{~A}$ & $9.69 \mathrm{~A}$ & $9.76 \mathrm{~A}$ & $9.93 \mathrm{~A}$ & 0.21 & & & \\
\hline d 7 & $11.27 \mathrm{~B}$ & $11.82 \mathrm{~B}$ & $11.47 \mathrm{~B}$ & $11.63 \mathrm{~B}$ & 0.21 & & & \\
\hline d 14 & $13.02 \mathrm{Cb}$ & $13.89 \mathrm{Ca}$ & $13.43 \mathrm{Ca}$ & $13.63 \mathrm{Ca}$ & 0.21 & & & \\
\hline d 21 & $14.86 \mathrm{Dc}$ & $16.37 \mathrm{Da}$ & $15.43 \mathrm{Db}$ & $15.76 \mathrm{Db}$ & 0.21 & & & \\
\hline d 28 & $17.23 \mathrm{Ec}$ & $18.80 \mathrm{Ea}$ & $18.05 \mathrm{~Eb}$ & $18.23 \mathrm{~Eb}$ & 0.21 & & & \\
\hline Average & $13.24 \mathrm{c}$ & $14.11 \mathrm{a}$ & $13.63 \mathrm{~b}$ & $13.83 \mathrm{ab}$ & 0.16 & & & \\
\hline \multicolumn{9}{|l|}{ Weight gain (kg) } \\
\hline d 1 to 14 & $3.22 \mathrm{c}$ & $4.21 \mathrm{a}$ & $3.67 \mathrm{~b}$ & $3.71 \mathrm{~b}$ & 0.18 & 0.01 & & \\
\hline d 14 to 28 & 4.21 & 4.91 & 4.61 & 4.59 & 0.23 & 0.22 & & \\
\hline d 1 to 28 & $7.42 \mathrm{c}$ & $9.11 \mathrm{a}$ & $8.28 \mathrm{~b}$ & $8.30 \mathrm{~b}$ & 0.33 & 0.01 & & \\
\hline \multicolumn{9}{|l|}{ Average daily gain $(\mathrm{kg} / \mathrm{d})$} \\
\hline d 1 to 14 & $0.230 \mathrm{c}$ & $0.300 \mathrm{a}$ & $0.262 \mathrm{~b}$ & $0.265 \mathrm{~b}$ & 0.01 & 0.01 & & \\
\hline d 14 to 28 & 0.300 & 0.350 & 0.329 & 0.328 & 0.02 & 0.22 & & \\
\hline $\mathrm{d} 1$ to 28 & $0.265 \mathrm{c}$ & $0.326 \mathrm{a}$ & $0.296 \mathrm{~b}$ & $0.296 \mathrm{~b}$ & 0.01 & 0.01 & & \\
\hline Silage intake (g DM/lamb/day) & $151.6 \mathrm{c}$ & $211.2 \mathrm{a}$ & $183.3 \mathrm{ab}$ & $175.3 \mathrm{bc}$ & 3.14 & 0.01 & & \\
\hline Concentrate intake (g DM/lamb/day) & $327.5 \mathrm{~b}$ & $388.8 \mathrm{a}$ & $339.6 \mathrm{~b}$ & $313.0 \mathrm{~b}$ & 2.74 & 0.01 & & \\
\hline Total solid intake (g DM/lamb/day) ${ }^{2}$ & $479.1 \mathrm{c}$ & $600.1 \mathrm{a}$ & $523.0 \mathrm{~b}$ & $488.4 \mathrm{~b}$ & 3.08 & 0.01 & & \\
\hline
\end{tabular}

${ }^{1}$ The treatments T1, T2, and T3 represent the groups supplemented with pepper extract at doses of $200 \mathrm{mg} / \mathrm{kg}$ of concentrate, $400 \mathrm{mg} / \mathrm{kg}$, and $800 \mathrm{mg} /$ $\mathrm{kg}$, respectively. ${ }^{2}$ Concentrate + silage per day (DM).

$\mathrm{a}-\mathrm{c}-$ within a row, values without a common letters differ $(\mathrm{P} \leq 0.05)$.

A-E - within treatment, values without a common letters differ $(\mathrm{P} \leq 0.05)$. 
Table 3. Serum biochemistry of lambs supplemented with pepper extract mixed in the concentrate

\begin{tabular}{|c|c|c|c|c|c|c|c|c|}
\hline \multirow{2}{*}{ Variables } & \multicolumn{4}{|c|}{ Treatments $^{1}$} & \multirow{2}{*}{ SEM } & \multicolumn{3}{|c|}{$\mathrm{P}$-value } \\
\hline & $\mathrm{C}$ & $\mathrm{T} 1$ & $\mathrm{~T} 2$ & $\mathrm{~T} 3$ & & treat & day & treat $\times$ day \\
\hline Albumin (g/dL) & & & & & & 0.50 & 0.01 & 0.15 \\
\hline d 1 & $2.67 \mathrm{~B}$ & 2.95 & $2.83 \mathrm{~A}$ & $2.89 \mathrm{~B}$ & 0.19 & & & \\
\hline d 15 & $3.07 \mathrm{AB}$ & 2.73 & $2.58 \mathrm{AB}$ & $2.82 \mathrm{~B}$ & 0.21 & & & \\
\hline d 28 & $3.37 \mathrm{~A}$ & 2.75 & $2.44 \mathrm{~B}$ & $3.41 \mathrm{~A}$ & 0.19 & & & \\
\hline Average & 3.03 & 2.81 & 2.95 & 3.04 & 0.12 & & & \\
\hline Globulin (g/dL) & & & & & & 0.43 & 0.01 & 0.03 \\
\hline d 1 & 3.04 & $2.99 \mathrm{~B}$ & $3.03 \mathrm{~B}$ & $3.03 \mathrm{~B}$ & 0.41 & & & \\
\hline d 15 & 3.16 & $3.26 \mathrm{~B}$ & $2.96 \mathrm{~B}$ & $3.15 \mathrm{~B}$ & 0.45 & & & \\
\hline d 28 & $3.20 \mathrm{c}$ & $4.46 \mathrm{Aa}$ & $4.43 \mathrm{Ab}$ & $4.78 \mathrm{Ab}$ & 0.41 & & & \\
\hline Average & 3.13 & 3.57 & 3.48 & 3.65 & 0.23 & & & \\
\hline Total protein $(\mathrm{g} / \mathrm{dL})$ & & & & & & 0.46 & 0.01 & 0.01 \\
\hline $\mathrm{d} 1$ & 5.75 & $5.90 \mathrm{~B}$ & $5.86 \mathrm{~B}$ & $5.89 \mathrm{~B}$ & 0.39 & & & \\
\hline d 15 & 6.27 & $5.95 \mathrm{~B}$ & $5.56 \mathrm{~B}$ & $5.94 \mathrm{~B}$ & 0.39 & & & \\
\hline $\mathrm{d} 28$ & $6.60 \mathrm{c}$ & $7.17 \mathrm{Abc}$ & $7.87 \mathrm{Aa}$ & $8.16 \mathrm{Ab}$ & 0.30 & & & \\
\hline Average & 6.21 & 6.34 & 6.43 & 6.67 & 0.21 & & & \\
\hline Urea (mg/dL) & & & & & & 0.23 & 0.01 & 0.57 \\
\hline d 1 & $29.91 \mathrm{~B}$ & $30.52 \mathrm{~B}$ & $30.47 \mathrm{~B}$ & $30.60 \mathrm{~B}$ & 4.00 & & & \\
\hline d 15 & $52.41 \mathrm{~A}$ & $60.36 \mathrm{~A}$ & $51.64 \mathrm{~A}$ & $55.10 \mathrm{~A}$ & 4.00 & & & \\
\hline $\mathrm{d} 28$ & $53.07 \mathrm{~A}$ & $67.36 \mathrm{~A}$ & $54.64 \mathrm{~A}$ & $54.60 \mathrm{~A}$ & 4.00 & & & \\
\hline Average & 45.13 & 52.75 & 45.58 & 46.77 & 2.85 & & & \\
\hline Cholesterol (mg/dL) & & & & & & 0.23 & 0.41 & 0.37 \\
\hline $\mathrm{d} 1$ & 81.12 & 76.98 & 78.99 & 81.07 & 9.30 & & & \\
\hline d 15 & 96.95 & 98.82 & 73.83 & 75.23 & 9.30 & & & \\
\hline d 28 & 101.29 & 90.82 & 76.16 & 75.07 & 9.30 & & & \\
\hline Average & 93.12 & 88.87 & 76.33 & 77.13 & 6.86 & & & \\
\hline Triglycerides (mg/dL) & & & & & & 0.85 & 0.86 & 0.74 \\
\hline d 1 & 52.97 & 48.51 & 53.88 & 51.09 & 6.69 & & & \\
\hline d 15 & 60.30 & 54.71 & 44.05 & 52.59 & 6.69 & & & \\
\hline $\mathrm{d} 28$ & 48.47 & 52.71 & 51.88 & 48.09 & 6.69 & & & \\
\hline Average & 53.91 & 51.97 & 49.94 & 50.60 & 4.12 & & & \\
\hline Glucose (mg/dL) & & & & & & 0.31 & 0.01 & 0.01 \\
\hline $\mathrm{d} 1$ & $119.55 \mathrm{~A}$ & $111.45 \mathrm{~A}$ & $117.69 \mathrm{~A}$ & $106.97 \mathrm{~A}$ & 5.24 & & & \\
\hline d 15 & $85.05 \mathrm{~B}$ & $90.78 \mathrm{~B}$ & $88.36 \mathrm{~B}$ & $93.81 \mathrm{~B}$ & 5.24 & & & \\
\hline $\mathrm{d} 28$ & $68.05 \mathrm{Cc}$ & $87.61 \mathrm{Bab}$ & $81.02 \mathrm{Bb}$ & $97.47 \mathrm{ABa}$ & 5.24 & & & \\
\hline Average & 90.89 & 96.61 & 95.69 & 99.42 & 3.09 & & & \\
\hline
\end{tabular}

${ }^{1}$ The treatments T1, T2 and T3 represent the groups supplemented with pepper extract at doses of $200 \mathrm{mg} / \mathrm{kg}$ of concentrate, $400 \mathrm{mg} / \mathrm{kg}$, and $800 \mathrm{mg} /$ $\mathrm{kg}$, respectively.

$\mathrm{a}-\mathrm{c}-$ within a row, values without a common letters differ $(\mathrm{P} \leq 0.05)$

A-C - within treatment, values without a common letters differ $(\mathrm{P} \leq 0.05)$.

\section{Hemogram}

The results of hematological parameters are shown in Table 4. Effects were detected for interaction between treatments $(\mathrm{P}=0.03)$ and day $(\mathrm{P}=0.01)$ for the hematocrit variable. T2 lambs showed higher hematocrit when compared to T0. Effects of the day $(\mathrm{P}=0.01)$ were detected for the erythrocyte count, where lambs T2 and T3 decreased over time. There were effects of treatment $(\mathrm{P}=0.01)$ and treatment versus day interaction $(\mathrm{P}=0.01)$ for leukocyte counts. Lambs in groups T2 and T3 had the highest counts of these cells (day 15) compared to T1 and T0. In all treatments supplemented with pepper extract, counts were higher (day 28) concerning T0, and on average, counts in lambs in groups T2 and T3 were also significantly higher than those of $\mathrm{T} 1$. There were effects between treatments $(\mathrm{P}=0.01)$, the day $(\mathrm{P}=0.02)$ and the treatment versus day interaction $(\mathrm{P}=0.02)$ for neutrophil counts. Lambs in groups T2 and T3 showed 
higher counts of neutrophil compared to animals from T0 and T1, with group T2 (day 15) being superior, followed by lambs T3 (day 28) compared to group T1 and T0. We detected effects on treatments $(P=0.03)$, on day $(\mathrm{P}=0.03)$ and on the treatment versus day $(\mathrm{P}=0.01)$ interaction for lymphocyte counts. Groups T2 and T3 had higher counts compared to T1, which in turn were greater than T0. Lambs in groups T2 and T3 had higher numbers of lymphocytes on day 15 . On day 28 , animals supplemented with pepper extract showed higher lymphocyte counts compared to T0. There were no effects between treatment, day, and treatment $\times$ day interaction for monocytes or eosinophils.

Table 4. Hemogram of lambs supplemented with pepper extract mixed in the concentrate

\begin{tabular}{|c|c|c|c|c|c|c|c|c|}
\hline \multirow{2}{*}{ Variables } & \multicolumn{4}{|c|}{ Treatments $^{1}$} & \multirow{2}{*}{ SEM } & \multicolumn{3}{|c|}{$\mathrm{P}$-value } \\
\hline & $\mathrm{C}$ & $\mathrm{T} 1$ & $\mathrm{~T} 2$ & $\mathrm{~T} 3$ & & treat & day & treat $\times$ day \\
\hline Hematocrit (\%) & & & & & & 0.03 & 0.01 & 0.37 \\
\hline d 1 & $27.69 \mathrm{~B}$ & $28.83 \mathrm{~B}$ & $30.13 \mathrm{~B}$ & $30.86 \mathrm{~B}$ & 0.87 & & & \\
\hline d 15 & $32.03 \mathrm{~A}$ & $33.17 \mathrm{~A}$ & $35.13 \mathrm{~A}$ & $31.86 \mathrm{~B}$ & 0.87 & & & \\
\hline d 28 & $33.86 \mathrm{~A}$ & $34.16 \mathrm{~A}$ & $34.53 \mathrm{~A}$ & $34.53 \mathrm{~A}$ & 0.87 & & & \\
\hline Average & $31.19 \mathrm{c}$ & $32.05 \mathrm{bc}$ & $33.26 \mathrm{a}$ & $32.42 \mathrm{ab}$ & 0.44 & & & \\
\hline Hemoglobin (g/dL) & & & & & & 0.44 & 0.01 & 0.68 \\
\hline d 1 & $9.09 \mathrm{~B}$ & $8.97 \mathrm{~B}$ & $9.29 \mathrm{~B}$ & $9.49 \mathrm{~B}$ & 0.25 & & & \\
\hline d 15 & $10.51 \mathrm{~A}$ & $10.99 \mathrm{~A}$ & $11.16 \mathrm{~A}$ & $10.68 \mathrm{~A}$ & 0.27 & & & \\
\hline $\mathrm{d} 28$ & $10.92 \mathrm{~A}$ & $11.29 \mathrm{~A}$ & $11.31 \mathrm{~A}$ & $11.27 \mathrm{~A}$ & 0.26 & & & \\
\hline Average & 10.17 & 10.42 & 10.59 & 10.48 & 0.17 & & & \\
\hline Erythrocytes $\left(\mathrm{x} 10^{6} \mu \mathrm{L}\right)$ & & & & & & 0.95 & 0.01 & 0.46 \\
\hline $\mathrm{d} 1$ & $8.79 \mathrm{AB}$ & $9.08 \mathrm{AB}$ & $9.61 \mathrm{~A}$ & 9.57 & 0.62 & & & \\
\hline d 15 & $9.95 \mathrm{~A}$ & $9.74 \mathrm{~A}$ & $8.93 \mathrm{AB}$ & 8.76 & 0.62 & & & \\
\hline $\mathrm{d} 28$ & $7.80 \mathrm{~B}$ & $8.31 \mathrm{~B}$ & $7.65 \mathrm{~B}$ & 8.36 & 0.62 & & & \\
\hline Average & 8.85 & 9.04 & 8.73 & 8.90 & 0.40 & & & \\
\hline Leukocytes $\left(\times 10^{3} \mu \mathrm{L}\right)$ & & & & & & 0.01 & 0.42 & 0.01 \\
\hline d 1 & 14.06 & 14.51 & 15.87 & 15.85 & 1.87 & & & \\
\hline d 15 & $9.66 \mathrm{~b}$ & $11.46 \mathrm{~b}$ & $17.50 \mathrm{a}$ & $15.37 \mathrm{a}$ & 1.87 & & & \\
\hline d 28 & $9.58 \mathrm{c}$ & $15.24 \mathrm{a}$ & $17.09 \mathrm{~b}$ & $17.13 \mathrm{~b}$ & 1.87 & & & \\
\hline Average & $11.10 \mathrm{c}$ & $13.74 \mathrm{~b}$ & $16.82 \mathrm{a}$ & $16.12 \mathrm{a}$ & 1.09 & & & \\
\hline Neutrophils $\left(\mathrm{x} 10^{3} / \mu \mathrm{L}\right)$ & & & & & & 0.01 & 0.02 & 0.02 \\
\hline $\mathrm{d} 1$ & 4.10 & 3.86 & $4.30 \mathrm{C}$ & $4.16 \mathrm{C}$ & 0.69 & & & \\
\hline d 15 & $3.07 \mathrm{c}$ & $4.02 \mathrm{c}$ & $8.48 \mathrm{Aa}$ & $5.94 \mathrm{Bb}$ & 0.69 & & & \\
\hline d 28 & $3.37 \mathrm{c}$ & $5.14 \mathrm{~b}$ & $6.38 \mathrm{Bab}$ & $6.80 \mathrm{Aa}$ & 0.69 & & & \\
\hline Average & $3.51 \mathrm{~b}$ & $4.34 \mathrm{~b}$ & $6.39 \mathrm{a}$ & $5.64 \mathrm{a}$ & 0.39 & & & \\
\hline Lymphocytes $\left(\times 10^{3} / \mu \mathrm{L}\right)$ & & & & & & 0.03 & 0.03 & 0.01 \\
\hline d 1 & $9.31 \mathrm{~A}$ & $9.99 \mathrm{~A}$ & 11.64 & 11.15 & 1.30 & & & \\
\hline d 15 & $5.81 \mathrm{Bb}$ & $6.75 \mathrm{Bab}$ & $10.68 \mathrm{a}$ & $8.66 \mathrm{a}$ & 1.30 & & & \\
\hline $\mathrm{d} 28$ & $5.84 \mathrm{Bb}$ & $9.51 \mathrm{ABa}$ & $9.90 \mathrm{a}$ & $9.64 \mathrm{a}$ & 1.30 & & & \\
\hline Average & $6.99 \mathrm{c}$ & $8.75 \mathrm{~b}$ & $10.74 \mathrm{a}$ & $9.82 \mathrm{a}$ & 0.75 & & & \\
\hline Monocytes $\left(\times 10^{3} / \mu \mathrm{L}\right)$ & & & & & & 0.07 & 0.66 & 0.06 \\
\hline d 1 & 0.54 & 0.57 & 0.66 & 0.64 & 0.09 & & & \\
\hline d 15 & 0.43 & 0.47 & 0.75 & 0.53 & 0.09 & & & \\
\hline d 28 & 0.39 & 0.59 & 0.58 & 0.71 & 0.09 & & & \\
\hline Average & 0.45 & 0.54 & 0.66 & 0.62 & 0.10 & & & \\
\hline Eosinophils $\left(\mathrm{x} 10^{3} / \mu \mathrm{L}\right)$ & & & & & & 0.84 & 0.50 & 0.42 \\
\hline $\mathrm{d} 1$ & 0.16 & 0.05 & 0.05 & 0.04 & 0.07 & & & \\
\hline d 15 & 0.06 & 0.12 & 0.19 & 0.19 & 0.07 & & & \\
\hline d 28 & 0.03 & 0.09 & 0.12 & 0.13 & 0.07 & & & \\
\hline Average & 0.08 & 0.09 & 0.12 & 0.12 & 0.04 & & & \\
\hline
\end{tabular}

${ }^{1}$ The treatments T1, T2 and T3 represent groups supplemented pepper extract at $200 \mathrm{mg} / \mathrm{kg}, 400 \mathrm{mg} / \mathrm{kg}$, and $800 \mathrm{mg} / \mathrm{kg}$ of concentrate, respectively. $\mathrm{a}-\mathrm{b}$ - within a row, values without a common letters differ $(\mathrm{P} \leq 0.05)$.

$\mathrm{A}-\mathrm{C}-$ within treatment, values without a common letters differ $(\mathrm{P} \leq 0.05)$. 
Table 5. Serum antioxidant response of lambs supplemented with pepper extract mixed in the concentrate

\begin{tabular}{|c|c|c|c|c|c|c|c|c|}
\hline \multirow{2}{*}{ Variables $^{1}$} & \multicolumn{4}{|c|}{ Treatments $^{2}$} & \multirow{2}{*}{ SEM } & \multicolumn{3}{|c|}{$\mathrm{P}$-value } \\
\hline & $\mathrm{C}$ & $\mathrm{T} 1$ & $\mathrm{~T} 2$ & $\mathrm{~T} 3$ & & treat & day & treat $\times$ day \\
\hline GST $(\mu \mathrm{mol} \mathrm{CDNB} / \mathrm{min})$ & & & & & & 0.25 & 0.11 & 0.34 \\
\hline d 1 & 40.57 & 50.77 & 49.27 & 45.22 & 7.21 & & & \\
\hline d 15 & 62.90 & 38.17 & 40.65 & 40.18 & 7.21 & & & \\
\hline $\mathrm{d} 28$ & 43.60 & 29.97 & 34.43 & 30.86 & 7.21 & & & \\
\hline Average & 49.02 & 39.63 & 41.45 & 38.75 & 3.90 & & & \\
\hline Thiols (mmol NPSH/mL) & & & & & & 0.73 & 0.01 & 0.45 \\
\hline d 1 & $0.026 \mathrm{~B}$ & $0.026 \mathrm{~B}$ & $0.026 \mathrm{~B}$ & 0.026 & 0.002 & & & \\
\hline d 15 & $0.032 \mathrm{~A}$ & $0.031 \mathrm{~A}$ & $0.027 \mathrm{~B}$ & 0.029 & 0.002 & & & \\
\hline $\mathrm{d} 28$ & $0.029 \mathrm{AB}$ & $0.031 \mathrm{~A}$ & $0.032 \mathrm{~A}$ & 0.026 & 0.002 & & & \\
\hline Average & 0.029 & 0.029 & 0.028 & 0.027 & 0.001 & & & \\
\hline ROS (U DCFA/ $\mu \mathrm{L})$ & & & & & & 0.12 & 0.32 & 0.05 \\
\hline d 1 & 5297.94 & 3223.16 & 4966.61 & 4803.74 & 451.97 & & & \\
\hline d 15 & 4556.14 & 5808.86 & 5130.14 & 4492.86 & 451.97 & & & \\
\hline $\mathrm{d} 28$ & $5184.49 \mathrm{a}$ & $4595.41 \mathrm{ab}$ & $4756.23 \mathrm{ab}$ & $3777.85 \mathrm{~b}$ & 451.97 & & & \\
\hline Average & 4816.50 & 4738.84 & 4951.00 & 4358.15 & 309.81 & & & \\
\hline TBARS (Mmol MDA/mL) & & & & & & 0.66 & 0.03 & 0.86 \\
\hline d 1 & $11.44 \mathrm{~A}$ & $11.45 \mathrm{~A}$ & 10.75 & 11.44 & 0.76 & & & \\
\hline d 15 & $9.72 \mathrm{~B}$ & $8.88 \mathrm{~B}$ & 10.27 & 10.34 & 0.76 & & & \\
\hline d 28 & $10.40 \mathrm{AB}$ & $10.03 \mathrm{AB}$ & 11.01 & 10.94 & 0.76 & & & \\
\hline Average & 10.52 & 10.12 & 10.68 & 10.91 & 0.46 & & & \\
\hline
\end{tabular}

${ }^{1}$ GST (glutathione S-transferase), ROS (species reactive to oxygen), TBARS (substances reactive to thiobarbituric acid). ${ }^{2} \mathrm{The}$ treatments T1, T2, and T3 represent groups supplemented with pepper extract at $200 \mathrm{mg} / \mathrm{kg}, 400 \mathrm{mg} / \mathrm{kg}$, and $800 \mathrm{mg} / \mathrm{kg}$ of concentrate, respectively.

$\mathrm{a}-\mathrm{b}$-within a row, values without a common letters differ $(\mathrm{P} \leq 0.05)$.

A-B - within treatment, values without a common letters differ $(\mathrm{P} \leq 0.05)$.

\section{Oxidant and antioxidant status}

The results of the oxidant and antioxidant status of lambs supplemented with pepper extract are shown in Table 5. Effects of the day $(\mathrm{P}=0.01)$ were detected for NPSH concentrations; T1 lambs showed that, over time, there was an increase in levels (day 1 to 15 ; day 1 to 28 ), and for animals in group $\mathrm{T} 2$, the concentrations also increased (day 1 to $30 ; 15$ to 28 ). We found effects in the treatment $\times$ day interaction $(\mathrm{P}=0.05)$ in the ROS concentrations, with T3 showing lower concentrations (day 28) than T0. For TBARS, we found effects on the day (P $=0.01$ ), i.e., we observed a decrease in T1 levels (days 1 to 15). We did not detect effects on the day, treatments, or treatment $\times$ day interaction $(\mathrm{P} \geq 0.11)$ for GST.

\section{Discussion}

The lowest dose of pepper extract (T1) resulted in lambs with greater body weights, weight gain, and DWG, which may have been related to higher feed consumption in these animals. In dairy ewes, the addition of pepper extract maintained lactation persistence in animals in the final third of production (Cunha et al., 2020). When beef cattle were supplemented with a product containing $1.1 \%$ capsaicinoids a trend toward an increase in the average daily gain of the animals was observed (Westphalen et al., 2021). When lambs were supplemented with $300 \mathrm{mg} / \mathrm{kg}$ of pepper extract no difference was observed in weight gain, average daily gain, or the consumption of dry matter (Ünlü et al., 2021); therefore, it does not corroborate what was found in the study, which demonstrates that $301.5 \mathrm{mg} / \mathrm{kg}$ of pepper extract according to the regression is an ideal dose to enhance the performance of lambs. However, when lambs were supplemented with unprotected capsaicin an improvement was observed in the consumption of dry matter and organic matter and even greater digestibility of dry matter, organic matter, indigestible fiber in neutral detergent, and indigestible fiber in acid detergent, largely due to the modulation of rumen fermentation that the capsaicin promoted in that study (Alford et al., 2016). Al-Kassie et al. (2012) found that the vitamin $\mathrm{C}$ present in pepper has an essential function in assisting in the digestion of food, which can explain the increase in lamb weight gain. Castillo et al. (2006) used $1 \mathrm{~g} / \mathrm{d}$ of capsicum extract (containing 15\% capsaicin) in beef heifers, and the animals showed higher consumption of total solids (roughage: concentrate) concerning other herbal extracts. In conjunction with the present experiment, these findings confirm the hypothesis that the active compound of pepper extract (capsaicin) increases appetite and consumption and may improve 
animal performance (Zafra et al., 2003; Abd El-Hack et al., 2019). In their study, Cunha et al. (2020) showed that sheep that consumed pepper extract consumed more water, which favors a greater consumption of food (silage and concentrate) for the animals in our research, explaining the greater weight gain of lambs. These findings found that these pepper compounds are solid candidates for replacing performance-enhancing antibiotics.

Lambs supplemented with powdered pepper extract had higher glucose levels than lambs that did not receive supplementation, but the levels were within the normal range for this animal. This positive effect occurs because glucose at ideal levels provides energy (ATP) to the body (Hsu et al., 2016), and capsaicin increases glucose uptake in muscle cells (Kim et al., 2013). When supplementing lambs with a mixture of capsicum and an artificial sweetener Chen et al. (2019) did not observe differences in blood glucose levels, which is not consistent with the present study; however, the authors found a predisposition to regulate insulin production without altering the blood glucose of the lambs, favoring the metabolism of animal carbohydrates. Hsu et al. (2016) further noted that capsaicin supplementation increases energy by stimulating increases in hepatic glycogen and improves performance in exercising mice. We measured increases in the levels of total proteins and globulins in the serum of lambs supplemented with pepper, similarly described in dairy ewes fed with $400 \mathrm{mg}$ pepper extract/ $\mathrm{kg} /$ day. However, in another recent study, the serum protein metabolism of lambs supplemented with capsicum extract was not altered. (Ünlü et al., 2021). Hack et al. (2013) reported higher serum levels of total protein in rabbits supplemented with a $0.5 \mathrm{~g}$ dose of black pepper + red pepper, demonstrating the difference between species and proving the need for further studies on the action of capsaicin on such metabolism. The increase in urea levels in both groups over time was proportional to the age of the growing animals, with no relation to the effect of the treatment.

The hematocrit was higher in the treated groups, in addition to a high increase in cell counts of leukocytes, neutrophils, and lymphocytes. Researchers observed an increase in neutrophils: lymphocytes on a given day of beef cattle experiment fed with a product containing $1.1 \%$ capsaicinoids (Westphalen et al., 2021). However, the authors demonstrate that the values were within the normal range, and such an increase can be represented by a possible reaction of the organism to animal stress. Lower levels of ROS were observed in the serum of lambs fed pepper extract. This is a positive result because when there is an increase in ROS levels, there is a greater production of free radicals that can damage the immune system of animals through the oxidation of cells (Barnes, 1990). The decrease in TBARS suggests a drop in lipid peroxidation; studies showed that capsaicin could perform this function; however, there was no difference between treatments in the present study, only as a function of time. The effect of capsaicin on the increase in the production of antioxidant enzymes has already been described (Hassan et al., 2012), similar to those observed in our study when we found a numerical increase in the concentration of thiols. Manjunatha and Srinivasan (2007) observed a 19\% decrease in total thiol levels in normal animals supplemented with capsaicin and a 38\% decrease in hypercholesterolemia. This compound helps mediate the adaptations to challenges; the increase in production occurs mainly due to possible oxidative stress (Adwas et al., 2019), suggesting that this increase is correlated with the age of lambs in which the body's defense mechanisms are adapting to adverse circumstances.

\section{Conclusion}

Pepper extract at a dose of $200 \mathrm{mg} / \mathrm{kg}$ stimulated intake and thereby favored weight gain. The regression analysis showed that the optimum point for pepper extract supplementation was $301.5 \mathrm{mg} / \mathrm{kg}$. The consumption of pepper extract also reduced ROS levels at the end of the experiment and stimulated the production of white cells (lymphocytes and neutrophils) and concentration of globulins in the serum of lactating lambs improving the animals' health.

\section{Ethical committee}

This work was submitted and approved by the UDESC Animal Use Ethics Committee under protocol number 6470081019

\section{References}

Abd El-Hack M.E., Alagawany M., Abdelnour S. (2019). Responses of growing rabbits to supplementing diet with a mixture of black and red pepper oils as a natural growth promoter. J. Anim. Physiol. Anim. Nutr. (Berl.), 103: 509-517.

Adwas A., Elsayed A., Azab A., Quwaydir F.A. (2019). Oxidative stress and antioxidant mechanisms in human body. J. Appl. Biotechnol. Bioeng, 6: 43.

Alford J.B., Castro J.G., Oosthuysen E.R., Rosasco S.L., Richins R.D. (2016). Effects of capsaicin source on blood capsaicin, glucose and insulin concentrations, rumen fermentation and nitrogen balance of sheep. J. Anim. Sci., 67: 171-175.

Ali S.F., LeBel C.P., Bondy S.C. (1992). Reactive oxygen species formation as a biomarker of methylmercury and trimethyltin neurotoxicity. Neurotoxicology, 13: 637-648.

Al-Kassie G.A., Butris G.Y., Ajeena S.J. (2012). The potency of feed supplemented mixture of hot red pepper and black pepper on the performance and some hematological blood traits in broiler diet. Int. J. Adv. Biol. Res., 2: 53-57.

AOAC (1997). Official methods of analysis. 18th edition. Association of Official Analytical Chemists.

Barnes P.J. (1990). Reactive oxygen species and airway inflammation. Free Radic. Biol. Med., 9: 235-243.

Castillo C., Benedito J.L., Vázquez P., Pereira V., Méndez J., Sotillo J., Hernández J. (2012). Effects of supplementation with plant extract product containing carvacrol, cinnamaldehyde and capsaicin on serum metabolites and enzymes during the finishing phase of feedlot-fed bull calves. Anim. Feed Sci. Technol., 171: 246-250.

Cazarotto C.J., Boito J.P., Gebert R.R., Reis J.H., Machado G., Bottari N.B., Morsch V.M., Schetinger M.R.C., Doleski P.H., Leal M.L.R., Baldissera M.D., Da Silva A.S. (2018). Metaphylactic effect of minerals on immunological and antioxidant responses, weight gain and minimization of coccidiosis of newborn lambs. Res. Vet. Sci., 121: 46-52. 
Cécere B.G., Alba D.F., Deolindo G.L., Araújo D.N., da Silva A.S (2020). Impact of dietary bee honey during first weeks of life in dairy lambs on growth and metabolism. Comp. Clin. Pathol., 29: 495-499.

Chen X.J., Nedelkov K., Oh J., Harper M.T., Wall E.H., Felix T.L., Hristov A.N. (2019). Effect of a blend of artificial sweetener and capsicum on productive performance and blood chemistry in growing lambs. Anim. Feed Sci. Technol., 258: 114308.

Cunha M.G., Alba D.F., Leal K.W., Marcon H., Souza C.F., Baldissera M.D., Paglia E.B., Kempka A.P., Vedovatto M., Zotti C.A., Da Silva A.S. (2020). Inclusion of pepper extract containing capsaicin in the diet of ewes in the mid-lactation period: effects on health, milk production, and quality. Res. Soc. Develop., 9: e46791110020.

De Oliveira M.V., Ferreira I.C., Júnior G.D.L.M., Rosalinski-Moraes F., Antunes M.M., França A.M.S., Naves J.G. Rodrigues V.J.C. (2013). Benefícios do uso da monensina sódica na nutrição de cordeiros semi-confinados (in Portuguese). Biosci. J., 29.

Feldman B.F. (2000). Schalm's Veterinary Hematology 5th ed. Wiley-Blackwell, Malden.

Frankic T., Levart A., Salobir J. (2010). The effect of vitamin E and plant extract mixture composed of carvacrol, cinnamaldehyde and capsaicin on oxidative stress induced by high PUFA load in young pigs. Animal, 4: 572.

Gu H., Yang Z., Yu W., Xu K., Fu Y.F. (2019). Antibacterial activity of capsaicin against sectional cariogenic bacteria. Pak. J. Zool., 51: 681.

Hassan M.H., Edfawy M., Mansour A., Hamed A.A. (2012). Antioxidant and antiapoptotic effects of capsaicin against carbon tetrachloride-induced hepatotoxicity in rats. Toxicol. Industr. Health, 28: 428-438.

Hernández-Castellano L.E., Moreno-Indias I., Morales-delaNuez A., Sánchez-Macías D., Torres A., Capote J., Castro N. (2015). The effect of milk source on body weight and immune status of lambs. Livest. Sci., 175: 70-76.

Hsu Y.J., Huang W.C., Chiu C.C., Liu Y.L., Chiu W.C., Chiu C.H., Chiu Y.S. Huang C.C. (2016). Capsaicin supplementation reduces physical fatigue and improves exercise performance in mice. $\mathrm{Nu}-$ trients, 8: 648.

Jamroz D., Orda J., Kamel C., Wiliczkiewicz A., Wertelecki T., Skorupinska J. (2003). The influence of phytogenic extracts on performance, nutrient digestibility, carcass characteristics, and gut microbial status in broiler chickens. J. Anim. Feed Sci., 12: 583-596.

Jarupan T., Rakangthong C., Bunchasak C., Poeikhampha T., Kromkhun P. (2018). Effect of colistin and liquid methionine with capsaicin supplementation in diets on growth performance and intestinal morphology of nursery pigs. Int. J. Pharm. Med. Biol. Sci., 7: $35-39$.

Jentzsch A.M., Bachmann H., Fürst P., Biesalski H.K. (1996). Improved analysis of malondialdehyde in human body fluids. Free Radic. Biol. Med., 20: 251-256.

Kim S.H., Hwang J.T., Park H.S., Kwon D.Y., Kim M.S. (2013). Capsaicin stimulates glucose uptake in $\mathrm{C} 2 \mathrm{C} 12$ muscle cells via the reactive oxygen species (ROS)/AMPK/p38 MAPK pathway. Biochem. Biophys. Res. Commun., 439: 66-70.

Komarek A.R. (1993). A filter bag procedure for improved efficiency of fiberanalysis. J. Dairy Sci., 76: 250.

Magalhães K., de Lucena C.C. (2019). Características e evolução da ovinocultura a partir dos dados definitivos do Censo Agropecuário de 2017. Embrapa Caprinos e Ovinos-Documentos (INFOTECA-E).

Manjunatha H., Srinivasan K. (2007). Hypolipidemic and antioxidant effects of dietary curcumin and capsaicin in induced hypercholesterolemic rats. Lipids, 42: 1133.

Mannervik B., Guthenberg C. (1981). Glutathione transferase (human placenta). In: Methods in Enzymology. Academic Press, 77: 231-235.

Marcon H., Baldissera M.D., Furlan V.J., Wagner R., Alba D.F., Molosse V.L. Cécere B.G.O., Da Silva A.S. (2020). Curcumin supplementation positively modulates fatty acid profiles in lamb meat. Small Rumin. Res., 106141.
Marcon H., Souza C.F., Baldissera M., Alba D., Favaretto J., Santos D., Borges L., Kessler J., Vedovatto M., Bianchi A., Da Silva A.S. (2021). Effect of curcumin dietary supplementation on growth performance, physiology, carcass characteristics and meat quality in lambs. Ann. Anim. Sci., 21: 623-638.

Mertens D.R. (2002). Gravimetric determination of amylase-treated neutral detergent fiber in feeds with refluxing in beakers or crucibles: collaborative study. J. AOAC Int., 85: 1217-1240.

Molosse V., Souza C.F., Baldissera M.D., Glombowsky P., Campigotto G., Cazaratto C.J., Stefani L.M. da Silva A.S. (2019). Diet supplemented with curcumin for nursing lambs improves animal growth, energetic metabolism, and performance of the antioxidant and immune systems. Small Rumin. Res., 170: 74-81.

Ochi T., Takaishi Y., Kogure K., Yamauti I. (2003). Antioxidant activity of a new capsaicin derivative from Capsicum annuиm. J. Nat. Prod., 66: 1094-1096.

Paim P.T., Cardoso M.T.M., Borges B.O., Gomes E.F., Louvandini H., McManus C. (2011). Estudo econômico da produção de cordeiros cruzados confinados abatidos em diferentes pesos (in Portuguese). Ciência Anim. Bras., 12: 48-57.

Peña-Alvarez A., Ramírez-Maya E., Alvarado-Suárez L.A. (2009). Analysis of capsaicin and dihydrocapsaicin in peppers and pepper sauces by solid phase microextraction-gas chromatography-mass spectrometry. J. Chromatogr. A., 1216: 2843-2847.

Pinto C.M.F., de Oliveira Pinto C.L., Donzeles S.M.L. (2013). Pimenta Capsicum: propriedades químicas, nutricionais, farmacológicas e medicinais e seu potencial para o agronegócio (in Portuguese). Rev. Bras. Agropec. Sustent., 3.

Rizzo P.V., Menten J.F.M., Racanicci A.M.C., Traldi A.B., Silva C.S., Pereira P.W.Z. (2010). Extratos vegetais em dietas para frangos de corte (in Portuguese). Rev. Bras. Zoot., 39: 801-807.

Santos E.L., Ludke M.C.M.M., Lima M.R. (2009). Extratos vegetais como aditivos em rações para peixes. Rev. Eletr. Nutr., 6: 789200.

Sedlak J., Lindsay R.H. (1968). Estimation of total, protein-bound, and nonprotein sulfhydryl groups in tissue with Ellman's reagent. Analytic. Biochem., 25: 192-205.

Senger C.C., Kozloski G.V., Sanchez L.M.B., Mesquita F.R., Alves T.P., Castagnino D.S. (2008). Evaluation of autoclave procedures for fibre analysis in forage and concentrate feedstuffs. Anim. Feed Sci. Technol., 146: 169-174.

Silva D.J., Queiroz A.C. (2002). Análises de alimentos (métodos químicos e biológicos) (in Portuguese). 3.ed. Viçosa MG: Editora $\mathrm{UFV}, 235 \mathrm{pp}$.

Stevanovic Z.D., Bošnjak-Neumüller J., Pajic-Lijakovic I., Raj J., Vasiljevic M. (2018). Essential oils as feed additives - future perspectives. Molecules, 23: 1717.

Ünlü H.B., İpçak H.H., Kandemir Ç., Özdoğan M., Canbolat O. (2021). Effects of oregano essential oil and capsicum extract on fattening, serum constituents, and rumen fermentation of lambs. South Afr. Soc. Anim. Sci., 51: 172-179.

Weiss W.P., Conrad H.R., Pierre N.S. (1992). A theoretically-based model for predicting total digestible nutrient values of forages and concentrates. Anim. Feed Sci. Technol., 39: 95-110.

Wesolowska A., Jadczak D., Grzeszczuk M. (2011). Chemical composition of the pepper fruit extracts of hot cultivars Capsicum annuum L. Acta Sci. Pol. Hort. Cult., 10: 171-184.

Westphalen M.F., Carvalho P.H., Oh J., Hristov A.N., Staniar W.B., Felix T.L. (2021). Effects of feeding rumen-protected Capsicum oleoresin on growth performance, health status, and total tract digestibility of growing beef cattle. Anim. Feed Sci. Technol., 271: 114778.

Zafra M.A., Molina F., Puerto A. (2003). Effects of perivagal administration of capsaicin on post-surgical food intake. Auton. Neurosci., 107: 37-44.

Received: 23 XII 2020

Accepted: 15 VII 2021 